\title{
Subclinical hypothyroidism in eastern Nepal: A hospital based study
}

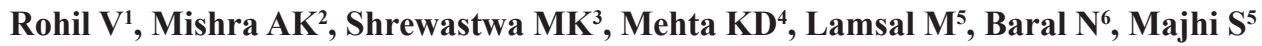

${ }^{1}$ Assistant Professor, Department of Clinical Biochemistry, Vallabhbhai Patel Chest Institute, University of Delhi, Delhi, India, ${ }^{2}$ Lecturer, Kathmandu Medical College, Kathmandu, Nepal, ${ }^{3}$ Medical Biochemistry student, ${ }^{4}$ Assistant Professor, ${ }^{5}$ Professor, ${ }^{6}$ Professor and Head, Department of Biochemistry, B.P. Koirala Institute of Health Sciences, Dharan, Nepal.

\begin{abstract}
Background: Subclinical hypothyroidism itself is associated with serious complications and also there is a known risk of subclinical hypothyroidism patients getting converted into overt disease.

Objectives: The objective of the present study was to find out the prevalence of subclinical hypothyroidism in the suspected cases i.e. amongst the cases attending the thyroid laboratory at B.P. Koirala Institute of Health Sciences, Dharan, Nepal.

Materials and methods: It was a retrospective cross sectional study. Data of the free $\mathrm{T}_{3}$, free $\mathrm{T}_{4}$ and TSH estimations of the year 2007 of the Thyroid lab at BPKIHS, Dharan, Nepal was analyzed. ELISA based free $\mathrm{T}_{3}$, free $\mathrm{T}_{4}$ and TSH tests in the serum had been performed in all the cases.

Results: Total cases were 1714 including $24.446 \%$ males and $75.554 \%$ females. Cases with raised TSH levels were $26.021 \%$, cases with normal TSH levels were $54.66 \%$ and cases with low TSH levels were $19.316 \%$. Total 350 cases $(20.42 \%)$ had subclinical hypothyroid dysfunction which includes 84 (4.901\%) males and $266(15.519 \%)$ females. And the maximum percentage of cases in either gender was between the age groups $20-59$ years.

Conclusion: The prevalence of subclinical thyroid hypothyroidism amongst the suspected cases was $20.42 \%$ which is much higher compared to the other parts of the world. The highest percentage was found in the female age group 20 -59 years. The routine screening of the whole population is not cost effective and on the basis of the present study it is suggested that there may be routine screening of the selected populations, especially women between 20 to 59 years of age in Nepal region. The preferred screening method advised is a sensitive ELISA based TSH test.
\end{abstract}

Key words: Subclinical hypothyroidism

$\mathrm{T}$ hyroid dysfunction is a major public health problem among the local population in Eastern Nepal ${ }^{1}$. Hypothyroidism results from inadequate production of thyroid hormone, and is classified as clinical or subclinical depending on the degree of clinical severity and the extent of abnormalities in thyroid indices. Subclinical hypothyroidism(SH) is defined as the clinical status of elevated serum TSH levels with normal levels of serum thyroxine $\left(\mathrm{T}_{4}\right)$ and triiodothyronine $\left(\mathrm{T}_{3}\right)$ and is a more common disorder than overt hypothyroidism with a prevalence of $1.4-7.8 \%$ in older populations and even greater percentiles among women ${ }^{2}$. SH is most commonly an early stage of hypothyroidism and is associated with few or no symptoms of hypothyroidism. The condition may resolve or remain unchanged, or may progress to overt hypothyroidism in a few years in some patients. SH holds a special importance as not only $\mathrm{SH}$ itself is associated with serious complications, but also, due to known risk of SH patients getting converted into overt disease which is approximately $5 \%$ per year ${ }^{3,4}$. In the management of such cases there are two crucial points which still continue to be controversial issues, the first is whether to go for a population screening for $\mathrm{SH}$ and the second is whether to treat $\mathrm{SH}$ or not. The available evidence is not sufficient to recommend for or against the screening or treatment of $\mathrm{SH}$, despite a welldocumented list of associated symptoms.

Today, it is accepted that most SH, like most overt hypothyroidism, is caused by autoimmune thyroid disease. Subclinical hypothyroidism also occurs in patients with infectious, silent, or postpartum thyroiditis, patients on excessive doses of anti-thyroid medications, lithium and other medications, patients with hypothyroidism who are on inadequate doses of replacement hormone, and patients with diminished

Correspondence

Dr. Vishwajeet Rohil

Assistant Professor

Department of Clinical Biochemistry,

Vallabhbhai Patel Chest Institute, University of Delhi

E-mail: vishir@rediffmail.com 
thyroid function related to permanent treatment for hyperthyroidism ${ }^{5}$. Subclinical hypothyroidism (SH) is a common disorder with a prevalence of $4-8.5 \%$ in the adult population in most community studies globally ranging from even as low as $1 \%$ to as high as $10 \%$ in some studies and the risk of developing $\mathrm{SH}$ increases with female gender and advanced age ${ }^{2,6-18}$.

The available evidence is not sufficient to recommend for or against the routine screening or treatment of $\mathrm{SH}$. Although the condition may resolve or remain unchanged, within a few years in some patients, overt hypothyroidism develops, with low thyroid hormones levels along with a raised TSH level. The likelihood that this will happen increases with greater TSH elevations and detectable antithyroid antibodies. Because patients with subclinical hypothyroidism sometimes have subtle hypothyroid symptoms and may have mild abnormalities of serum lipoproteins and cardiac function, patients with definite and persistent TSH elevation should be considered for thyroid treatment. Levothyroxine, in a dosage that maintains serum TSH levels within the normal range, is the preferred therapy in these patients ${ }^{5}$. Unfortunately, treatment is often withheld in SH despite a well-documented list of associated symptoms. These include most commonly elevated lipid levels and others including cardiac abnormalities, congestive heart failure, latency of motor nerve conduction, increased intraocular pressure, arthralgia, depression and cognitive changes. A recent study by Walsh, et al ${ }^{19}$. confirmed that subclinical hypothyroidism, but not subclinical hyperthyroidism, is associated with an increase in fatal and nonfatal coronary heart disease. SH, women older than 50 years of age with markedly elevated TSH levels ( $>10 \mathrm{mIU} / \mathrm{L}$ ) have the highest risk for complications. $\mathrm{SH}$ is known to be associated with dyslipidemia leading to increased risk of atherosclerosis. Some studies have indicated that $\mathrm{SH}$ is with increased risk of CAD, especially in women with antibodies to thyroid peroxidase as well as in smokers, the SH-induced lipid abnormalities offering the most obvious explanation for this association ${ }^{17,20}$. Moreover, SH impairs ventricular function as well as cardiovascular and respiratory adaptation to effort $^{20}$. Although it is clear that thyroid replacement therapy has beneficial effects on the serum lipid profile and on the risk of CAD in patients with overt hypothyroidism, the question of whether SH should be treated or not remains unanswered ${ }^{21}$.

Several studies have shown that a modest fraction of patients with subclinical hypothyroidism (approximately 3 to $5 \%$ per year, depending on age and magnitude of TSH elevation) within a few years have progression to overt hypothyroidism with a decline in serum free thyroxine concentration ${ }^{3,4}$. Approximately $18 \%$ of elderly patients with elevated $\mathrm{TSH}$ but normal $\mathrm{FT}_{4}$ will develop low $\mathrm{FT}_{4}$ when followed for 12 months ${ }^{10}$. The hypothyroidism complications are known to have serious consequences e.g. in children it may lead to mental retardation, deafness and ataxia, lower IQ, delayed sexual maturation and the onset of puberty etc. Hypothyroidism during fetal/post-natal life interferes with the normal development of CNS and increases infant mortality, congenital abnormalities, stunted growth and dwarfism and is associated with a waddling gait, etc. In adults the hypothyroidism may be responsible for reduced fertility, impaired mental function, CHD and atherosclerosis, anaemia, pleural effusion, reduced appetite, constipation, delayed muscle contraction and relaxation, decreased renal blood flow and glomerular filtration rate, etc. In pregnant women hypothyroidism leads to abortion and premature delivery, still birth or birth of congenitally defective babies. Considering the above potential dangers of hypothyroidism, there needs to be proper guidelines to recommend the screening and treatment of SH if not in a general population, at least in a selected population as there is a potential danger to progression to overt disease state.

Recommendations about thyroid screening, however, have been inconsistent. American Thyroid Association recommends that adults be screened for thyroid dysfunction by measurement of the serum thyrotropin concentration, beginning at age 35 years and every 5 years thereafter particularly in women. Individuals with symptoms and signs potentially attributable to thyroid dysfunction and those with risk factors for its development may require more frequent serum thyrotropin testing. According to American College of Physicians, and American Academy of Family Physicians, there is insufficient evidence to recommend routine screening 5 . The U.S. Preventive Services Task Force concludes the evidence is insufficient to recommend for or against routine screening for thyroid disease in adults ${ }^{22}$. And some authors ${ }^{23}$ have recommended testing in women more than 40 years of age and in geriatric patients. Danese and co-workers ${ }^{24}$ demonstrated through a decision model that $\mathrm{TSH}$ screening every five years, starting at age 35 , was costeffective because progression to overt hypothyroidism was prevented, serum cholesterol levels were reduced and symptoms were relieved with early treatment of hypothyroidism. The American Thyroid Association recommends that adults be screened for thyroid dysfunction by measurement of the serum thyrotropin concentration, beginning at age 35 years and every 5 years thereafter ${ }^{25}$.

\section{Materials and methods}

It was a hospital based retrospective cross sectional study. Data of the free $\mathrm{T}_{3}$, free $\mathrm{T}_{4}$ and TSH estimations of the period of 1 year w.e.f. $1^{\text {st }}$ Jan 2007 to $31^{\text {st }}$ 
December 2007 at the Thyroid lab at BPKIHS, Dharan was analysed. The data source used was from the register maintained at the Thyroid lab, Department of Biochemistry, BPKIHS, Dharan, Nepal with permission from the department. Free $T_{3}$, free $T_{4}$ and $\mathrm{TSH}$ estimations in the serum had been performed in the morning samples in all the cases after an overnight fast of 12 hours by the Enzyme-linked immunosorbent assays using Human kits. While analysing data every precaution was taken to exclude the follow up cases, thus repeat tests of the same persons were excluded and only their first estimations were included.

The normal reference range of serum TSH in our Biochemistry Thyroid lab using Human kits was 0.4 - $6.2 \mathrm{mIU} / \mathrm{L}$ with sensitivity $0.1 \mathrm{mIU} / \mathrm{L} \mathrm{TSH}$ and high specificity as the cross-reactivities were found to be $100 \%$ with TSH and $0.1 \%$ with FSH, LH \& HCG. Criteria for $\mathrm{SH}$ in our studies were serum TSH more than $6.2 \mathrm{mIU} / \mathrm{L}$ with normal range of serum free $\mathrm{T}_{3}(1.4-4.2$ $\mathrm{pg} / \mathrm{ml}) \&$ serum free $\mathrm{T}_{4}(0.8-2.2 \mathrm{ng} / \mathrm{dl})$. The criteria for the overt hypothyroidism taken were elevated serum TSH level above the upper normal reference level i.e. $6.2 \mathrm{mIU} / \mathrm{L}$ in our laboratory with low $\mathrm{T}_{3}$ and thyroxine levels.

\section{Results}

Total cases were 1714 including 419 (24.446\%) males and 1295 (75.554\%) females. Cases with raised TSH levels were $446(26.021 \%)$, cases with normal TSH levels were $937(54.66 \%)$ and cases with low TSH levels were $331(19.316 \%)$ [Figure-1]. Age-sex wise distribution of all the cases in various groups is shown in Table-1. Serum hormone levels in various groups are shown in Table- 2 and 3 . Total 350 cases $(20.42 \%$ of total 1714 cases) had subclinical hypothyroid dysfunction which includes 84 (4.901\%) males and 266 (15.519 $\%$ ) females [Table-4]. Age-sex wise distribution of SH cases demonstrated that $77.38 \%$ of males and $86.09 \%$ of females were between the age groups $20-59$ years [Table-6].

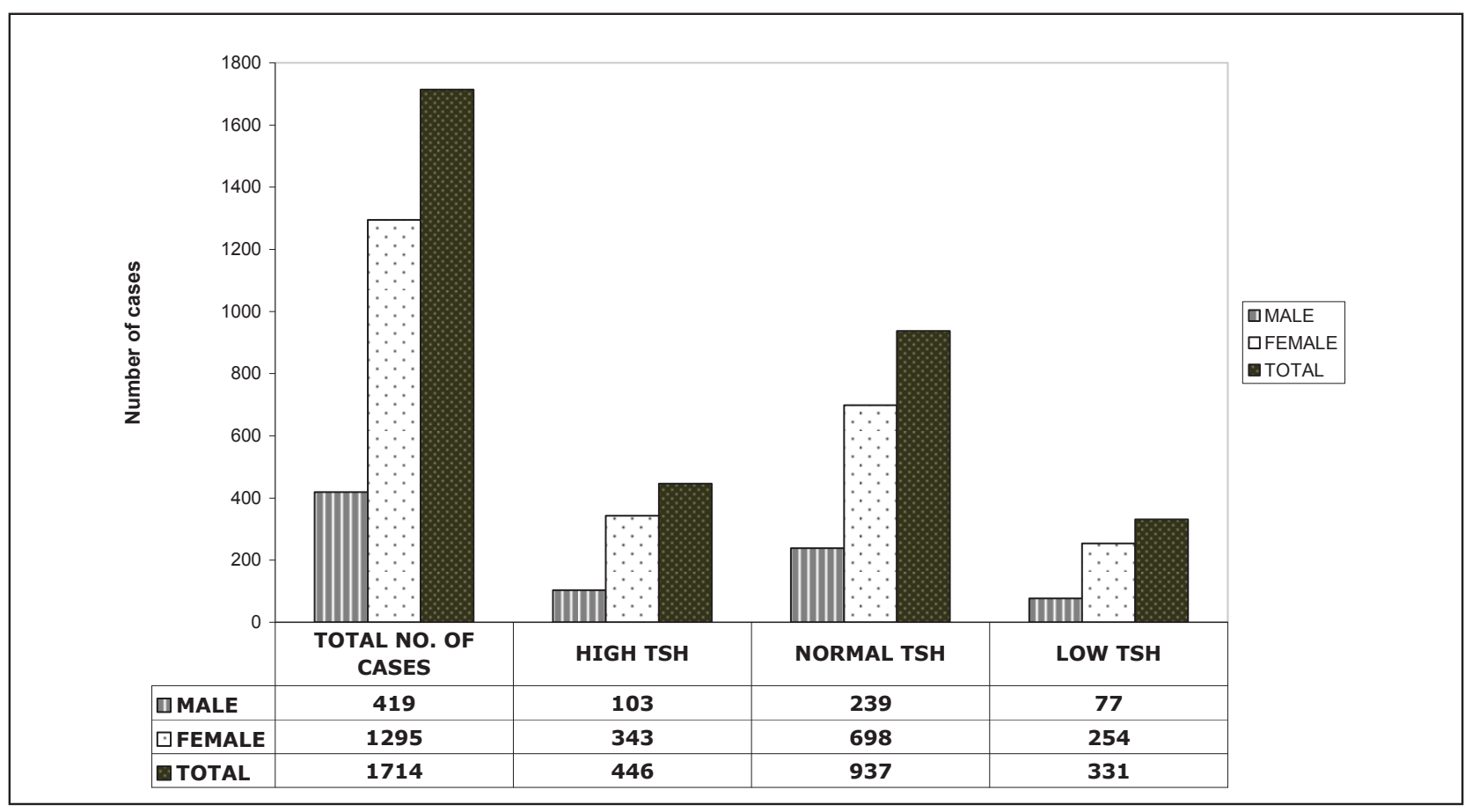

Fig 1: Number of cases in each group 
Table 1: Age-sex wise distribution of all the cases

\begin{tabular}{|c|c|c|c|c|c|c|}
\hline $\begin{array}{c}\text { Age Group } \\
\text { Years }\end{array}$ & $\begin{array}{c}\text { Total } \\
\mathbf{n}=\mathbf{1 7 1 4}\end{array}$ & $\begin{array}{c}\text { Total Males } \\
\mathbf{n}=\mathbf{4 1 9}\end{array}$ & $\begin{array}{c}\text { Total Females } \\
\mathbf{n = 1 2 9 5}\end{array}$ & $\begin{array}{c}\text { High tsh } \\
\text { Group } \\
\mathbf{n}=\mathbf{4 4 6}\end{array}$ & $\begin{array}{c}\text { Normal tsh } \\
\text { group } \\
\mathbf{n}=\mathbf{9 3 7}\end{array}$ & $\begin{array}{c}\text { Low tsh } \\
\text { Group } \\
\mathbf{n}=\mathbf{3 3 1}\end{array}$ \\
\hline $0-9$ years & $52[3.0 \%]$ & $23[5.5 \%]$ & $29[2.24 \%]$ & 20 & 26 & 6 \\
\hline $10-19$ years & $125[7.3 \%]$ & $36[8.6 \%]$ & $89[6.9 \%]$ & 33 & 74 & 18 \\
\hline $20-29$ years & $418[24.4 \%]$ & $126[30.1 \%]$ & $292[22.5 \%]$ & 112 & 235 & 71 \\
\hline $30-39$ years & $401[23.4 \%]$ & $81[19.3 \%]$ & $320[24.7 \%]$ & 108 & 221 & 72 \\
\hline $40-49$ years & $362[21.1 \%]$ & $61[14.6 \%]$ & $301[23.2 \%]$ & 105 & 181 & 76 \\
\hline $50-59$ years & $213[12.4 \%]$ & $51[12.2 \%]$ & $162[12.5 \%]$ & 40 & 125 & 48 \\
\hline $60-69$ years & $100[5.8 \%]$ & $27[6.4 \%]$ & $73[5.6 \%]$ & 20 & 55 & 25 \\
\hline$>70$ years & $43[2.5 \%]$ & $14[3.3 \%]$ & $29[2.2 \%]$ & 8 & 20 & 15 \\
\hline
\end{tabular}

$\mathrm{n}=$ Number of cases

Table 2: Classification based on serum TSH levels

\begin{tabular}{|l|c|c|c|}
\hline \multirow{2}{*}{ Classification } & \multicolumn{3}{|c|}{$\begin{array}{c}\text { Serum Hormone Levels } \\
\text { Mean } \pm \text { SD }\end{array}$} \\
\cline { 2 - 4 } & ${\text { Free } \mathbf{T}_{3}}^{\text {Free } \mathbf{T}_{4}}$ & TSH \\
\hline Reference range & $1.4-4.2 \mathrm{pg} / \mathrm{ml}$ & $0.8-2.2 \mathrm{ng} / \mathrm{dl}$ & $0.4-6.2 \mathrm{mIU} / \mathrm{L}$ \\
\hline $\begin{array}{l}\text { Multiplied by conversion factor } \\
\text { SI units }\end{array}$ & $\mathrm{x} 1.54 \mathrm{pmol} / \mathrm{L}$ & $\mathrm{x} 12.87 \mathrm{pmol} / \mathrm{L}$ & $\mathrm{x} 1 \mathrm{mIU} / \mathrm{L}$ \\
\hline Total $\mathrm{n}=1714$ & $3.100 \pm 2.272$ & $1.548 \pm 1.056$ & $5.433 \pm 7.372$ \\
\hline $\begin{array}{l}\text { High tsh group } \\
\mathrm{n}=419\end{array}$ & $2.196 \pm 0.787$ & $1.093 \pm 0.383$ & $14.940 \pm 8.799$ \\
\hline Normal tsh group $\mathrm{n}=937$ & $2.750 \pm 0.888$ & $1.382 \pm 0.392$ & $2.778 \pm 1.619$ \\
\hline Low tsh group $\mathrm{n}=331$ & $5.310 \pm 4.166$ & $2.630 \pm 1.903$ & $0.139 \pm 0.107$ \\
\hline
\end{tabular}

$\mathrm{n}=$ Number of cases

High TSH Group = Subclinical Hypothyroid + Overt Hypothyroid

Normal TSH Group = Euthyroid

Low TSH Group = Subclinical Hyperthyroid + Overt Hyperthyroid

Table 3: Hormone levels in various SH groups

\begin{tabular}{|l|c|c|c|}
\hline \multirow{2}{*}{ SH groups } & \multicolumn{3}{|c|}{$\begin{array}{c}\text { Serum hormone levels } \\
\text { Mean } \pm \text { SD }\end{array}$} \\
\cline { 2 - 4 } & ${\text { Free } \mathbf{T}_{\mathbf{3}}}^{*}$ Free $\mathbf{T}_{4}$ & TSH \\
\hline Reference range & $1.4-4.2 \mathrm{pg} / \mathrm{ml}$ & $0.8-2.2 \mathrm{ng} / \mathrm{dl}$ & $0.4-6.2 \mathrm{mIU} / \mathrm{L}$ \\
\hline $\begin{array}{l}\text { Multiplied by conversion factor } \\
\text { SI units }\end{array}$ & $\mathbf{x} \mathbf{1 . 5 4} \mathbf{~ p m o l} / \mathbf{L}$ & $\mathbf{x} \mathbf{1 2 . 8 7} \mathbf{~ p m o l} / \mathbf{L}$ & $\mathbf{x} \mathbf{1} \mathbf{~ m I U / L}$ \\
\hline Total SH & $2.465 \pm 0.581$ & $1.235 \pm 0.269$ & $12.759 \pm 7.373$ \\
\hline SH male & $2.544 \pm 0.576$ & $1.257 \pm 0.249$ & $11.954 \pm 6.426$ \\
\hline SH female & $\mathbf{2 . 4 4 0} \pm \mathbf{0 . 5 8 0}$ & $\mathbf{1 . 2 2 8} \pm \mathbf{0 . 2 7 5}$ & $\mathbf{1 3 . 0 1 4} \pm \mathbf{7 . 6 4 1}$ \\
\hline
\end{tabular}


Table 4: Raised TSH levels in Males and Females

\begin{tabular}{|l|c|c|c|c|}
\hline Case Description & \multicolumn{1}{|c|}{ Male N= 103 Out Of 419 M } & \multicolumn{2}{|c|}{ Female N=343 Out of 1295 F } \\
\hline & $\begin{array}{c}\text { Subclinical } \\
\text { Hypothyroid } \\
\mathrm{n}=84\end{array}$ & $\begin{array}{c}\text { Overt Hypothyroid } \\
\mathrm{n}=19\end{array}$ & $\begin{array}{c}\text { Subclinical } \\
\text { Hypothyroid } \\
\mathrm{n}=266\end{array}$ & $\begin{array}{c}\text { Overt Hypothyroid } \\
\mathrm{n}=77\end{array}$ \\
\hline $\begin{array}{l}4.901 \% \\
\text { \% of Total Cases ( } \mathrm{n}=1714)\end{array}$ & $1.109 \%$ & $15.519 \%$ & $4.492 \%$ \\
\hline $\begin{array}{l}\mathrm{n}=446 \text { of All Cases With High TSH } \\
\text { \% of Respective Sex Group With } \\
\text { High TSH [M }=103, \mathrm{~F}=343]\end{array}$ & $\mathbf{8 1 . 5 5 3 \%}$ & $\mathbf{1 8 . 4 4 7 \%} \%$ & $59.641 \%$ & $17.265 \%$ \\
\hline
\end{tabular}

$\mathrm{n}=$ Number of cases

Total number of SH Cases $=84+266=350$

Prevalence of SH in suspected cases $=4.901 \%+15.519 \%=20.42 \%$

Table 5: Age-sex wise distribution of cases in High TSH and SH Groups

\begin{tabular}{|c|c|c|c|c|c|c|c|c|}
\hline & \multicolumn{2}{|c|}{$\begin{array}{c}\text { Females with High } \\
\text { TSH }\end{array}$} & \multicolumn{2}{c|}{ Males with High TSH } & \multicolumn{2}{c|}{ SH Females } & \multicolumn{2}{c|}{ SH Males } \\
\hline Age GR & $\mathbf{T = 3 4 3}$ & $\mathbf{\%}$ & $\mathbf{T}=\mathbf{1 0 3}$ & $\mathbf{\%}$ & $\mathbf{T}=\mathbf{2 6 6}$ & $\mathbf{\%}$ & $\mathbf{T}=\mathbf{8 4}$ & $\%$ \\
\hline $\mathbf{0}-\mathbf{9}$ years & $\mathbf{8}$ & $2.33 \%$ & $\mathbf{1 2}$ & $11.65 \%$ & $\mathbf{5}$ & $1.88 \%$ & $\mathbf{1 2}$ & $14.29 \%$ \\
\hline $10-19$ years & $\mathbf{2 4}$ & $7.0 \%$ & $\mathbf{9}$ & $8.74 \%$ & $\mathbf{1 8}$ & $6.77 \%$ & $\mathbf{8}$ & $9.52 \%$ \\
\hline $20-29$ years & $\mathbf{8 3}$ & $24.2 \%$ & $\mathbf{2 9}$ & $28.16 \%$ & $\mathbf{6 4}$ & $24.06 \%$ & $\mathbf{2 2}$ & $26.19 \%$ \\
\hline $30-39$ years & $\mathbf{9 3}$ & $27.11 \%$ & $\mathbf{1 5}$ & $14.56 \%$ & $\mathbf{7 3}$ & $27.44 \%$ & $\mathbf{1 2}$ & $14.29 \%$ \\
\hline $40-49$ years & $\mathbf{8 7}$ & $25.36 \%$ & $\mathbf{1 8}$ & $17.48 \%$ & $\mathbf{7 2}$ & $27.07 \%$ & $\mathbf{1 6}$ & $19.05 \%$ \\
\hline $50-59$ years & $\mathbf{3 1}$ & $9.04 \%$ & $\mathbf{9}$ & $8.74 \%$ & $\mathbf{2 0}$ & $7.52 \%$ & $\mathbf{7} \%$ & $8.33 \%$ \\
\hline $60-69$ years & $\mathbf{1 3}$ & $3.79 \%$ & $\mathbf{7}$ & $4.37 \%$ & $\mathbf{1 0}$ & $3.76 \%$ & $\mathbf{5}$ & $5.95 \%$ \\
\hline$>70$ years & $\mathbf{4}$ & $1.66 \%$ & $\mathbf{4}$ & $3.88 \%$ & $\mathbf{4}$ & $1.50 \%$ & $\mathbf{2}$ & $2.38 \%$ \\
\hline
\end{tabular}

\section{Discussion}

The objective of the present study was to find out the prevalence of subclinical hypothyroidism in the suspected cases i.e. amongst the cases attending the thyroid lab at B.P. Koirala Institute of Health Sciences, Dharan, Nepal. In the present study, the total number of patients with raised TSH levels which includes $\mathrm{SH}$ and overt hypothyroidism were 446 which including 103 males and 343 females. Among the 103 males with raised TSH, 84 males or $81.5 \%$ had SH and only 19 or $18.45 \%$ had full blown overt hypothyroid state. Among the 343 females with raised TSH, 266 (77.55\%) females had SH and 77 (22.45\%) had full blown overt hypothyroid state. Thus total $350(20.42 \%$ of total 1714 cases) had subclinical hypothyroid dysfunction including 84 males and 266 females. The prevalence of $\mathrm{SH}$ in the suspected male cases was $4.901 \%$ and in the suspected female cases was $15.519 \%$ and the overall prevalence in the suspected cases taken together thus was $20.42 \%$ which is much higher as compared to the prevalence found in the other epidemiological studies in the other parts of the world which ranges from as low as $1 \%$ to an average of $4-8.5 \% \%^{2,6-18}$. The results of the present study though much higher but are in agreement with the data across the world in terms of high prevalence of $\mathrm{SH}$ among females. As there was an overall much higher percentage of female subjects (75.554\%) compared to males $(24.446 \%)$ consequently the number of female subjects was much higher in both high $\mathrm{TSH}$ and $\mathrm{SH}$ groups compared to males as shown in the table-4. Age-sex wise distribution of $\mathrm{SH}$ cases (Table-5) has demonstrated that $77.38 \%$ of males and $86.09 \%$ of females were between the age groups 20 - 59 years which is slightly higher as compared to the overall distribution of cases with males $76.2 \%$ and females $82.9 \%$ in the age groups 20 - 59 years (Table1). The highest percentage of SH cases was thus found in the female age group 20 - 59 years.

As this is a hospital based study so naturally the positive cases are expected more but it gives an idea about the high incidence rates in the society as well but for getting a clear picture an extensive epidemiological study is required. In one of the study conducted at BPKIHS in 2002, a total of 599 cases were studied during a single year and the cases with raised TSH were $17.19 \%$ with slightly higher prevalence among terai castes $(17.66 \%)$ when compared with hill castes $(15.17 \%) .{ }^{1}$ But till date no detailed study in this region is available for subclinical 
hypothyroidism though there are a few studies available on iodine deficiency disorders in Nepal and one of the study showed a decline in the prevalences of iodine deficiency disorders among Sherpa residents of the Khumbu region of Nepal but still iodine deficiency continued to be a major problem in Khumbu and demanded a clear control strategy, combining ongoing iodine supplementation and education ${ }^{26}$.

At this juncture, evidence does not support the routine universal screening for $\mathrm{SH}$ or recommend for the treatment of $\mathrm{SH}^{5,21,22}$. The routine universal screening for $\mathrm{SH}$ is not cost effective especially in the developing countries but considering the potential known danger of $\mathrm{SH}$ itself being associated with serious complications especially in females above 50 years $^{17,20}$ and also due to a known risk of substantial number of $\mathrm{SH}$ patients getting converted into overt disease ${ }^{3,4}$, we feel that some strategy should be formalised for the screening of $\mathrm{SH}$ and the undertaken study provides support for the screening in selected populations. The American Thyroid Association recommends that adults be screened for thyroid dysfunction by measurement of the serum thyrotropin concentration, beginning at age 35 years and every 5 years thereafter ${ }^{25}$. But considering a higher percentage of cases in the female reproductive age groups in Eastern Nepal found in the present study especially in the younger 20 to 39 years age groups and also taking into consideration the potential danger of hypothyroidism to the pregnant women and the developing foetus we recommend the screening to be started as early as 20 years and every 5 years thereafter rather than 35 years as advised by the American Thyroid Association. The two recommended methods for thyroid hormonal assays are RIA and ELISA for their high sensitivity and specificity. Because for the known drawbacks with RIA as it is not only very costly to perform but also there is potential danger of radioactivity hazards, special training to the lab personnel is required and special precautions need to be taken. On the other hand ELISA technique is not only cost effective and easy to perform but is also equally highly sensitive and specific. Especially in a country like Nepal where cost effectiveness is an essential requirement ELISA technique is recommended by us for not only for TSH but also for other hormonal assays. The preferred screening method advised is a sensitive ELISA based TSH test. But further work is needed to establish the optimum strategy for screening. As it was a hospital based study, the results may not be applicable to the general population as follow up patients from the previous years or from other centres cannot be ruled out despite taking precautions to exclude such patients. Therefore it is suggested that an extensive epidemiological studies should be carried out.

\section{Conclusion}

A higher prevalence of $\mathrm{SH}$ was expected as thyroid dysfunction is a major public health problem among the local population in Eastern $\mathrm{Nepal}^{1}$ but exact prevalence was not known and this is the first study in this direction. The study revealed percentage of subclinical hypothyroidism among the patients referred to thyroid lab at B.P.K.I.H.S. in Eastern Nepal is 20.42 $\%$ representing the prevalence amongst the suspected cases which is quite high as compared to the prevalence found in the other epidemiological studies in the other parts of the world which ranges from as low as $1 \%$ to an average of $4-8.5 \%$. The highest percentage of SH cases was found especially in the female age group $20-59$ years. Considering the potential danger to progression to overt disease state and also SH may itself associated with serious complications, there needs to be proper guidelines to recommend the screening and treatment of SH. As the routine screening of the whole population is not cost effective thus on the basis of the present study it is suggested that there may be routine screening of the selected populations, especially women between 20 to 59 years of age in Nepal region, starting at the age of 20 years and every 5 years thereafter. The preferred screening method advised is a sensitive ELISA based TSH test. As it was a hospital based study, further epidemiological studies are required.

\section{References}

1. Baral N, Lamsal M, Koner BC, Koirala S. Thyroid Dysfunction in Eastern Nepal. Southeast Asian J Trop Med Public Health. 2002;33(3):638-41.

2. Cooper DS. Subclinical thyroid disease: a clinician's perspective. Annals of Internal Medicine. 1998;129:135-8.

3. Samuels MH. Subclinical thyroid disease in the elderly. Thyroid. 1998;8:803-13.

4. Huber G, Staub JJ, Meier C, Mitrache C, Guglielmetti M, Huber P, et al. Prospective study of the spontaneous course of subclinical hypothyroidism: prognostic value of thyrotropin, thyroid reserve, and thyroid antibodies. J Clin Endocrinol Metab. 2002;87(7):3221-6.

5. Adlin Victor. Subclinical Hypothyroidism: Deciding When to Treat, American Family Physician. American Family Physician. 1998;57(4):776.

6. Nystrom E, Bengtsson C, Lindquist O, Noppa $\mathrm{H}$, Lindstedt G, Lundberg PA. Thyroid disease and high concentration of serum thyrotropin in a population sample of women. Acta Med Scand. 1981;210:39-46. 
7. Falkenberg M, Kagedal B, Norr A. Screening of an elderly female population for hypo- and hyperthyroidism by use of a thyroid hormone panel. Acta Med Scand. 1983;214:361-5.

8. Sawin CT, Castelli WP, Hershman JM, McNamara P, Bacharach P. The aging thyroid. Thyroid deficiency in the Framingham Study. Arch Intern Med. 1985;145:1386-8.

9. Okamura K, Nakashima T, Ueda K, Inoue K, Omae T, Fujishima M. Thyroid disorders in the general population of Hisayama Japan, with special reference to prevalence and sex differences. Int J Epidemiol. 1987;16:545-9.

10. Parle JV, Cross FKW, Jones SC, Sheppard MC. Prevalence and follow-up of abnormal thyrotrophin (TSH) concentrations in the elderly in the United Kingdom. Clin Endocrinol (Oxf). 1991;34:77-83.

11. Konno N, Yuri K, Taguchi H, Miura K, Taguchi S, Hagiwara K, Murakami S. Screening for thyroid diseases in an iodine sufficient area with sensitive thyrotropin assays, and serum thyroid autoantibody and urinary iodide determinations. Clinical Endocrinology. 1993;38(3):273-81.

12. Konno N, Makita H, Yuri K, Iizuka N, Kawasaki $\mathrm{K}$. Association between dietary iodine intake and prevalence of subclinical hypothyroidism in the central regions of Japan. J Clin Endocrinol Metab. 1994;78:393-7.

13. Vanderpump MPJ, Tunbridge WMG, French JM, Appleton D, Bates D, Clark F, et al. The incidence of thyroid disorders in the community - a twenty-year follow-up of the Whickham Survey. Clinical Endocrinology. 1995;43(1):5568.

14. Danese D, Arduino G, Andreoli M, Pontecorvi A. Screening for subclinical hypothyroidism in a flight personnel population. Thyroid. 1997;7: S-61.

15. Knudsen $\mathrm{N}$, Jorgensen $\mathrm{T}$, Rasmussen $\mathrm{S}$, Christiansen E, Perrild H. The prevalence of thyroid dysfunction in a population with borderline iodine deficiency. Clin Endocrinol (Oxf). 1999;51(3):361-7.
16. Canaris GJ, Manowitz NR, Mayor G, Ridgway EC. The Colorado thyroid disease prevalence study. Arch Intern Med. 2000;160:526-34.

17. Hak AE, Pols HAP, Visser TJ, Drexhage HA, Hoffman A, Witteman JCM. Subclinical hypothyroidism is an independent risk factor for atherosclerosis and myocardial infarction in elderly women: the Rotterdam Study. Ann Intern Med. 2000;132:270-8.

18. Pirich C, Mullner M, Sinzinger H. Prevalence and relevance of thyroid dysfunction in 1922 cholesterol screening participants. J Clin Epidemiol. 2000; 53(6):623-9.

19. Walsh JP, Bremner AP, Bulsara, MK, O'Leary P, Leedman PJ, Feddema P, et al. Subclinical thyroid dysfunction as a risk factor for cardiovascular disease. Arch Intern Med. 2005; 165:2467-72.

20. Kahaly GJ. Cardiovascular and atherogenic aspects of subclinical hypothyroidism. Thyroid. 2000;10:665-79.

21. Liberopoulos EN, Elisaf MS. Dyslipidemia in patients with thyroid disorders. Hormones (Athens). 2002;1(4):218-23.

22. US. Preventive Services Task Force. Screening for Thyroid Disease: Recommendation Statement. Ann Intern Med. 2004; 140:125127.

23. Helfand M, Crapo LM. Screening for thyroid disease. Ann Intern Med. 1990;112:840-9.

24. Danese MD, Powe NR, Sawin CT, Ladenson PW. Screening for mild thyroid failure at the periodic health examination: a decision and costeffectiveness analysis. JAMA. 1996;276:28592.

25. Ladenson PW, Singer PA, Ain KB, Bagchi $\mathrm{N}$, Bigos ST, Levy EG, et al. American Thyroid Association Guidelines for Detection of Thyroid Dysfunction. Arch Intern Med. 2000;160(11):1573-5.

26. Murdoch DR, Harding EG, Dunn JT. Persistence of iodine deficiency 25 years after initial correction efforts in the Khumbu region of Nepal. N Z Med J. 1999; 112(1092):266-8. 